\begin{tabular}{|c|c|c|}
\hline $\begin{array}{l}\text { Vol. 60: 87-89, } 2014 \\
\text { doi: } 10.3354 / \mathrm{cr} 01228\end{array}$ & $\begin{array}{c}\text { CLIMATE RESEARCH } \\
\text { Clim Res }\end{array}$ & Published online June 3 \\
\hline
\end{tabular}

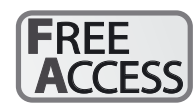

\title{
NOTE
}

\section{Local-scale adaptation to climate change: the village flower festival}

\author{
Tim H. Sparks* \\ Chair of Ecoclimatology, Technische Universität München, Hans-Carl-von-Carlowitz-Platz 2, 85354 Freising, Germany \\ Institute for Advanced Study, Technische Universität München, Lichtenbergstrasse 2a, 85748 Garching, Germany \\ Institute of Zoology, Poznań University of Life Sciences, Wojska Polskiego 71C, 60-625 Poznań, Poland \\ sigma, Coventry University, Priory Street, Coventry CV1 5FB, UK \\ Department of Zoology, University of Cambridge, Downing Street, Cambridge CB2 3EJ, UK
}

\begin{abstract}
Plant tourism, for example to view flower displays or autumn colours, is a worldwide industry worth billions of US dollars annually. Climate change has been modifying the timings of many of these plant events, but there is little evidence of adaptation to meet this challenge. Here I show that a local-scale festival attracting thousands of people annually has advanced its timing by more than 3 wk over $46 \mathrm{yr}$. This short paper represents one of the first solid pieces of evidence of adaptation in flower tourism. I believe that these events represent a neglected source of data for confirming responses to a changing climate and, worldwide, it is likely that festivals can provide numerous such examples.
\end{abstract}

KEY WORDS: Adaptation $\cdot$ Climate change $\cdot$ Daffodil $\cdot$ Flower festival $\cdot$ Narcissus $\cdot$ Synchrony

Resale or republication not permitted without written consent of the publisher

\section{INTRODUCTION}

Plant tourism is big. It is a major cultural ecosystem service. Across the world, festivals, estates, and garden and nature reserves attract huge number of tourists to witness and celebrate flowering, harvest and fall events. The timings of many of these events have been changing in recent years as a consequence of a changing climate (Rosenzweig et al. 2007). However, there is little evidence that plant tourism is adapting to climate change (Scott et al. 2006), even when key players are aware of the issue (Sakurai et al. 2011).

The small village of Thriplow, $13 \mathrm{~km}$ south of Cambridge, UK, has hosted a Daffodil Weekend every year since 1969, with the exception of 2001 when the event planned for March 31 to April 1 was cancelled because of movement restrictions following a natio- nal outbreak of foot-and-mouth disease. This village, with a population of $\sim 450$, now welcomes 8000 to 10000 visitors over the Daffodil Weekend.

In this short study, I investigate whether the timing of this local flower festival has changed over its $46 \mathrm{yr}$ history and how this human decision compares with changes in actual flowering dates recorded nearby. In so doing, I hope to encourage researchers around the world to investigate whether adaptation of plant tourism to the effects of climate change is more widespread than currently believed.

\section{METHODS}

Dates of the Daffodil Weekends were obtained from the village website (www.thriplow.org.uk), from archive copies of the Cambridge News, Royston Crow 
and village newsletter, and from village residents. The planned (revised) date for the 2014 weekend was obtained from the village website. The Saturday of the weekend was converted into the sequential day of the year ( 1 = January 1 , etc.) and used in analyses.

The late John Clarke, a farmer from Swaffham Prior some $22 \mathrm{~km}$ NE of Thriplow, recorded a wide range of phenological events from 1966 to 2003 (Hannant \& Sparks 2008). I have taken his first flowering date of daffodil (variety unspecified) for the years 1969 to 2003 for comparison with the Thriplow dates. First flowering dates were also converted to days of the year prior to analysis, and are hereafter referred to as daffodil FFD.

Monthly mean Central England temperatures (CET) were obtained from the UK Met Office Hadley Centre website (www.metoffice.gov.uk/hadobs/ hadcet).

Trends in the first day of the Daffodil Weekend and in daffodil FFD were estimated from regression of day of year values on year. Since dates of the Daffodil Weekend are planned 18 months in advance, the 'response' of the first day of the Daffodil Weekend to temperature was obtained from regression of day of year values on spring temperatures 2 yr previously. The cancelled 2001 date was included in all analyses. Timings of the Daffodil Weekend and daffodil FFD were compared using a paired $t$-test.

\section{RESULTS}

The dates of the Daffodil Weekend have varied by $41 \mathrm{~d}$ with the latest date being April 26 to 27, 1969 and the earliest March 16 to 17, 2013. There has been a highly significant advance in the dates of the Daffodil Weekend (slope, $b=-0.561 \pm 0.068 \mathrm{~d} \mathrm{yr}^{-1}$, $\left.\mathrm{R}^{2}=61.0 \%, \mathrm{p}<0.001\right)$ equating to an advance of $26 \mathrm{~d}$ over the 46 yr (Fig. 1). Daffodil FFD was more variable with a range of $66 \mathrm{~d}$, occurring on average $37 \mathrm{~d}$ earlier than the Daffodil Weekend (Fig. 1; paired $\left.t_{33}=14.20, \mathrm{p}<0.001\right)$. The trend in daffodil FFD $\left(b=-0.522 \pm 0.266 \mathrm{~d} \mathrm{yr}^{-1}, \mathrm{R}^{2}=10.8 \%, \mathrm{p}=\right.$ $0.058)$ did not differ significantly $\left(F_{1,76}=0.03, \mathrm{p}=\right.$ 0.866) from that of the Daffodil Weekend, but was not significant in its own right because of the greater variability in the record. The average interval between daffodil FFD and the weekend would be sufficient for daffodils to progress to full flowering display. Given that the dates of the Daffodil Weekend are set 18 months in advance, the weak correlation with daffodil FFD ( $r=0.334, p=0.054)$ is not surprising. Daffodil Weekend dates were signifi-

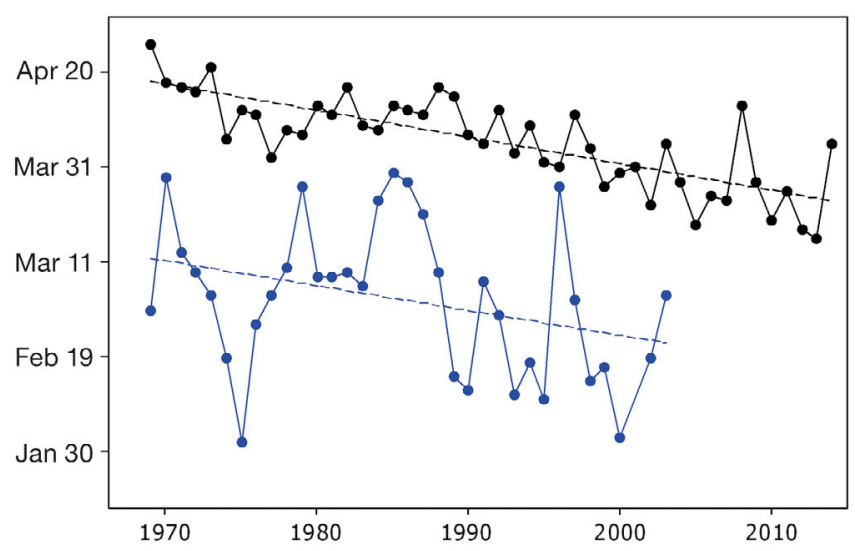

Fig. 1. Dates of the first day of the Thriplow Daffodil Weekend, Cambridgeshire, UK, 1969 to 2014 (in black), and the first flowering date of daffodils recorded by John Clarke at Swaffham Prior, Cambridgeshire, UK, 1969 to 2003 (in blue). Regressions are shown as dashed lines

cantly correlated with February, March and April (but not January) mean temperatures 2 yr previously. Regression of Daffodil Weekend on mean March to April temperature 2 yr previously (Fig. 2; $b=-6.6 \pm 1.2 \mathrm{~d}{ }^{\circ} \mathrm{C}^{-1}, \mathrm{R}^{2}=41.9 \%, \mathrm{p}<0.001$ ) suggested that warm springs were associated with a decision to advance the Daffodil Weekend $2 \mathrm{yr}$ hence. The daffodil FFD examined here were strongly linked to mean January to March temperature of the same year (Fig. $2 ; b=-10.1 \pm 1.2 \mathrm{~d}^{\circ} \mathrm{C}^{-1}$, $\left.\mathrm{R}^{2}=68.3 \%, \mathrm{p}<0.001\right)$.

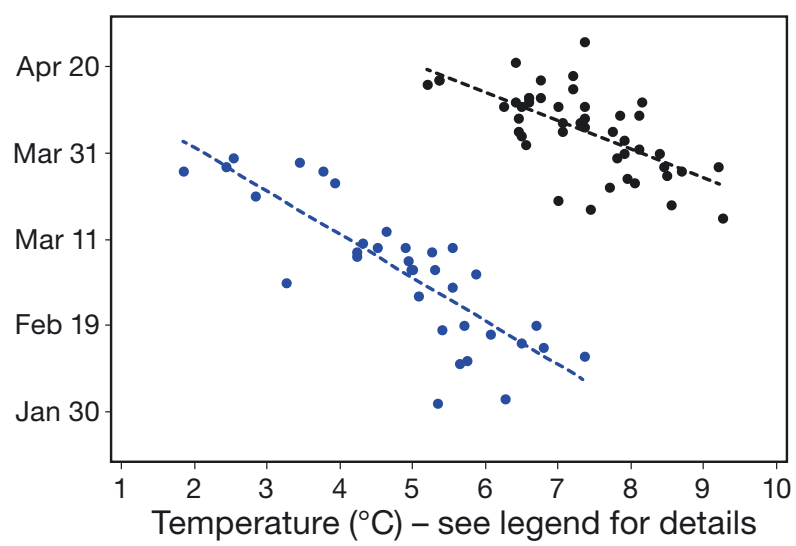

Fig. 2. Dates of the first day of the Thriplow Daffodil Weekend, Cambridgeshire, UK, 1969 to 2014 (in black) plotted against mean March to April temperature 2 yr previously, and the first flowering date of daffodils recorded by John Clarke at Swaffham Prior, Cambridgeshire, UK, 1969 to 2003 (in blue) plotted against mean January to March temperature of the same year. Regressions are shown as dashed lines 


\section{DISCUSSION}

Some (more famous) flower festivals, such as the cherry blossom festivals in Kyoto, Japan (Aono \& Kazui 2008) and Washington, DC, USA (Chung et al. 2011), are triggered by the flowering of the plants themselves. Other flower festivals may be held on fixed dates (e.g. public holidays) each year, such as the Ottawa tulip festival in Canada. However, the festival at Thriplow has to predict the daffodil flowering some considerable time in advance to accommodate advance planning of coach tours and so forth. Consequently there have been years when the best of the daffodils had passed, and others where the event was held too early, for example, in 1979 when only one daffodil was reported to be in flower. Problem years were likely those when the interval between the arranged date for the weekend and the start of daffodil flowering was too great or too narrow (for example, 1975 or 1996 when the 2 lines in Fig. 1 diverge or converge respectively). Commercially, it is well known that daffodil flowering date responds to rising spring temperature (Hanks 2002), and this is confirmed here for the local daffodil first flowering dates. Precipitation effects are of minor importance in locations where spring soil moisture is not limited (A. Bock pers. comm.). Organisers have had to adapt to the advanced flowering attributed to climate warming by gradually advancing the weekend. On average, the advance in Daffodil Weekend dates matches - almost exactly - that of local first flowering of daffodil. Consequently, again on average, the arranged flower festival dates have advanced at an appropriate rate, although matching in individual years may not be perfect. The date for 2014 was recently rearranged backwards by $14 \mathrm{~d}$, in a response to the very cold and late spring of 2013 ('the coldest March since 1962' www.metoffice.gov.uk/climate/ uk/summaries/2013/march). However, such changes are rare and disrupt advance planning. Organisers have also been hedging their bets by planting a wider range of cultivars with a considerable spread of flower timing. However, this has not prevented the need to advance the festival; it has, however, made a floral display more reliable in recent years.

Changes made in the timing of the Thriplow Daffodil Weekend underline the need for adaption to a changing climate. Mean March to April temperatures in Central England have risen considerably since the Daffodil Weekend was founded (for 1969 to 2013: $b=0.040 \pm 0.010^{\circ} \mathrm{C} \mathrm{yr}^{-1}, \mathrm{R}^{2}=27.0 \%, \mathrm{p}<0.001$ ) equating to a rise of $1.8^{\circ} \mathrm{C}$. Clearly, the organisers of the weekend are adapting to that changing climate and demonstrating other adaptation strategies, such as planting a wide range of daffodil maturities. Evidence for adaptation in flower tourism is scant (Scott et al. 2006), but some adaptation includes the delay of tulip flowering in Canada by increasing snow cover, mulching or irrigation and a wider spread of varietal maturities (Scott et al. 2009). Flower festival organisers are aware of a changing climate, but responses to this are currently varied (Sakurai et al. 2011). The timings of flower festivals worldwide, which vary from year to year, may provide another useful indicator of how climate change is affecting the way we organise our flower and tree tourism. This cultural aspect of ecosystem services ranges in size from the attractions of small nature reserves (e.g. Sparks et al. 2012) to countrywide cherry blossom festivals, with a total value likely to run into billions of US dollars. I envisage that plant tourism will be a fruitful area of research into the effects of climate change over the coming years.

\section{LITERATURE CITED}

Aono Y, Kazui K (2008) Phenological data series of cherry tree flowering in Kyoto, Japan, and its application to reconstruction of springtime temperatures since the 9th century. Int J Climatol 28:905-914

Chung U, Mack L, Yun JI, Kim SH (2011) Predicting the timing of cherry blossoms in Washington, DC and midAtlantic states in response to climate change. PLoS ONE 6:e27439

Hanks GR (ed) (2002) Narcissus and daffodil: the genus Narcissus. Taylor \& Francis, London

Hannant G, Sparks T (2008) Phenological changes in Cambridgeshire. Nat Cambridgeshire 50:85-91

Rosenzweig C, Casassa G, Karoly DJ, Imeson A and others (2007) Assessment of observed changes and responses in natural and managed systems. In: Parry ML, Canziani OF, Palutikof JP, van der Linden PJ, Hanson CE (eds) Climate change 2007: impacts, adaptation and vulnerability. Contribution of Working Group II to the Fourth Assessment Report of the Intergovernmental Panel on Climate Change. Cambridge University Press, Cambridge, p 79-131

Sakurai R, Jacobson SK, Kobori H, Primack R, Oka K, Komatsu N, Machida R (2011) Culture and climate change: Japanese cherry blossom festivals and stakeholders' knowledge and attitudes about global climate change. Biol Conserv 144:654-658

Scott D, Jones B, McBoyle G (2006) Climate, tourism and recreation: a bibliography 1936 to 2006. University of Waterloo, Ontario

Scott D, de Freitas C, Matzarakis A (2009) Adaptation in the tourism and recreation sector. In: Ebi KL, Burton I, McGregor GR (eds) Biometeorology for adaptation to climate variability and change. Springer, Dordrecht, p 171-194

Sparks TH, Mizera T, Wójtowicz W, Tryjanowski P (2012) Synchrony in the phenology of a culturally iconic spring flower. Int J Biometeorol 56:407-409

Submitted: January 17, 2014; Accepted: March 25, 2014

Proofs received from author(s): May 27, 2014 